\title{
Differential Characteristics of Strains of Rochalimaea: Rochalimaea vinsonii sp. nov., the Canadian Vole Agent
}

\author{
EMILIO WEISS AND GREGORY A. DASCH \\ Naval Medical Research Institute, Bethesda, Maryland 20814
}

\begin{abstract}
A series of comparative studies was carried out on the Fuller and Guadalupe strains of Rochalimaea quintana and the vole agent described by Baker in 1946. No differences were encountered between the two strains of $R$. quintana. The vole agent resembled $R$. quintana in most of its phenotypic characteristics, but, in contrast to $R$. quintana, did not require $\mathrm{CO}_{2}$ for growth, catabolized glutamate without an added energy-yielding substrate, and autoagglutinated. Comparisons of the migration patterns of various protein fractions in gels by sodium dodecyl sulfate-polyacrylamide gel electrophoresis, line-rocket immunoelectrophoresis, and enzyme-specific staining confirmed the identity of the two strains of $R$. quintana and their similarity to the vole agent. Although many of the proteins had the same function as enzymes in $R$. quintana and the vole agent or reacted equally well with both homologous and heterologous sera, they migrated at different rates in the gels. Therefore, on the basis of this and previously reported evidence, we propose that the vole agent be named Rochalimaea vinsonii sp. nov. This name honors J. William Vinson, who, in collaboration with Henry S. Fuller, established that $R$. quintana can be grown axenically and initiated studies of the genus Rochalimaea by conventional bacteriological techniques. The type strain of $R$. vinsonii is ATCC VR-152.
\end{abstract}

Trench fever made its first explosive appearance during World War I, where it caused the loss of more man-days in the armed forces than any other disease except influenza (28). After the war, trench fever as a clinical entity disappeared just as rapidly as it had appeared, but it reappeared on a more limited scale again in Europe during World War II (32). This infection probably has a worldwide distribution since a small outbreak was reported from Ethiopia (6), a case was reported from Tunisia (27), and its presence has been repeatedly demonstrated in Mexico $(30,31)$.

During the first 45 years of investigation of trench fever, the etiological agent, Rochalimaea quintana, was cultivated only with enormous difficulty. This organism is not infectious for the common laboratory animals (18), and its growth in the yolk sacs of chicken embryos is scanty (34). Rochalimaea quintana was maintained in lice that were fed on human volunteers, who often became infected $(18,28)$.

Perhaps the first successful cultivation of $\mathrm{Ro}$ chalimaea quintana on bacteriological media was achieved in 1921 by Sikora (26), who inoculated human blood agar with the coelomic fluid of highly infected lice and reported the appearance of small grayish white colonies after 20 days of incubation at $37^{\circ} \mathrm{C}$. This author also reported that inactivation of the blood at $57^{\circ} \mathrm{C}$ enhanced growth and that the organisms could be cultivated with horse blood but not rabbit blood. Unfortunately, Sikora believed that she was culturing a harmless louse parasite, Rickettsia pediculi, rather than Rochalimaea quintana, and she did not pursue her studies. We now believe that the two designations refer to the same microorganism (41). In 1957 Pshenichnov (23) claimed to have grown Rochalimaea quinta$n a$ in a medium consisting of defibrinated human blood, egg yolk, and milk. This report was received with skepticism because some of the statements of this author contradicted the experience of other investigators (33). Pshenichnov stated that the microorganisms were anaerobic and infected young white mice, and, in a later paper (24), Pshenichnov et al. reported that a similar medium supported limited growth of Rickettsia prowazekii.

In 1960, Vinson and Fuller (34) accomplished the axenic growth of Rochalimaea quintana. Lice infected with the Osijek strain of Rochalimaea quintana, which was furnished by Mooser (18), were fed on Fuller, who experienced a typical course of trench fever. A specimen of his blood obtained during early convalescence was shown to be infectious for lice and to produce small colonies on blood agar. Fluorescent antibody tests indicated that Fuller had developed antibodies to the organisms cultivated on blood agar. In later experiments, Vinson et al. (35) fulfilled Koch's postulates by inducing typical 
clinical trench fever in volunteers infected with microorganisms passaged exclusively on blood agar.

The medium of Vinson and Fuller (34) consisted of blood agar base supplemented with $10 \%$ freshly drawn defibrinated horse or human blood. This and subsequent (33) work established that increased $\mathrm{CO}_{2}$ pressure, aerobic conditions, and a factor in erythrocytes were essential for the growth of Rochalimaea quintana, whereas serum was stimulatory. Myers et al. $(19,20)$ showed that in agar, as well as in liquid medium, the erythrocyte requirement could be replaced by hemoglobin or hemin and that serum could be replaced by a "detoxifying agent," such as starch or charcoal. Mason (16) showed that fetal calf serum (FCS), but not calf serum, could replace the erythrocyte lysate requirement in a liquid medium containing, in addition, yeast extract (YE), sodium chloride, and an organic buffer. Huang (10) demonstrated that Rochalimaea quintana utilizes several substrates, including succinate, glutamine, and glutamate, and Myers et al. (20) showed that the addition of succinate and glutamate to their medium also stimulated growth.

The Canadian vole agent was described in 1946 by Baker (2), who isolated it from voles (Microtus pennsylvanicus) captured on Grosse Isle, Quebec, Canada. This island had served as a quarantine station during the height of the immigration from Ireland during the 19th century, and thousands of immigrants had died of typhus there. The reason for the studies of Baker was the belief that the epidemic of the previous century might have left a vestige in the local fauna, but Baker recognized that the agent which he had isolated was not a typhus rickettsia. In 1978 , we $(17,39)$ investigated the properties of the vole agent and showed that it closely resembled Rochalimaea quintana in morphological, cultural, and other biological properties. The vole agent killed chicken embryos with great irregularity and developed small colonies after 4 to 7 days of cultivation on blood agar. This organism lacked glycolytic enzymes, as is the case in Rochalimaea quintana and the rickettsiae $(7,10,39)$, but metabolized succinate, pyruvate, and glutamine in a manner comparable to that of Rochalimaea quintana (10). The deoxyribonucleic acid (DNA) base ratio of the vole agent was identical to that of Rochalimaea quintana (39 mol\% guanine plus cytosine) ( 22 , 29,30 ), and it reacted with sera elicited against Rochalimaea quintana. It was further shown that Rochalimaea quintana and the vole agent multiplied quite well on the surfaces of eucaryotic cells and in a manner similar to that observed in the guts of trench fever-infected lice $(11,28)$. We concluded (39) that the vole agent, although not identical to Rochalimaea quintana in metabolic and antigenic properties, should be regarded as a strain of Rochalimaea quintana, at least until detailed comparative studies established the relationship between the two microorganisms.

Subsequent studies $(22,38)$ have emphasized the differences rather than the similarities between Rochalimaea quintana and the vole agent. The migration patterns of solubilized proteins in polyacrylamide gels displayed variations comparable to those found in comparisons of Rickettsia prowazekii and Rickettsia typhi (8), and the DNAs of the two microorganisms hybridized to the extent of 31 to $42 \%$ (22).

The purpose of this study was to compare the cultural, biochemical, and antigenic properties of two strains of Rochalimaea quintana and the vole agent and to propose an appropriate classification for the latter organism.

\section{MATERIALS AND METHODS}

Passage histories of strains. The origins and early passages of the Fuller and vole agent strains have been described previously $(17,39)$. The Guadalupe strain (32) was isolated on blood agar in Mexico City from the blood of a volunteer infected by scarification with a saline suspension of body lice collected in a public dormitory. A seed from the 10th blood agar passage was kindly sent to us by the late J. W. Vinson of Harvard University.

The 13th and 11th passages of the Fuller and Guadalupe strains, respectively, and the 44th chicken embryo passage of the vole agent were passed twice in modified cell culture medium (MEM medium [see below]) and plated at high dilutions onto blood agar (blood agar base [Difco Laboratories, Detroit, Mich.] supplemented with $4 \%$ FCS and $6 \%$ sheep erythrocytes washed twice in phosphate-buffered saline [PBS] and lysed in an equal volume of distilled water). Individual colonies were transferred to tubes containing $4 \mathrm{ml}$ of MEM medium and further passaged in larger volumes of this medium. Most of the subsequent experiments were done with the harvests from the second to fourth passages after clone isolation.

The MEM medium used consisted of Eagle minimal essential medium containing $25 \mathrm{mM}$ HEPES $(N-2-$ hydroxyethylpiperazine- $N^{\prime}$-2-ethanesulfonic acid) buffer (pH 7.2 to 7.4; GIBCO Laboratories, Grand Island, N.Y.), $10 \%$ FCS, $0.1 \%$ YE (Difco), 2 mM glutamine, $1 \mathrm{mM}$ succinate, and 4.5 to $6.0 \mathrm{mM}$ sodium bicarbonate.

Nutritional experiments. All media to be tested were dispensed in 5-ml volumes into screw-capped tubes $(100$ by $16 \mathrm{~mm})$, and experiments were done in triplicate. Occasionally, the seal of a tube was not tight and allowed the escape of $\mathrm{CO}_{2}$. Such tubes were identified by the purple color of the phenol red $\mathrm{pH}$ indicator and were discarded. Each inoculum was prepared from 30 to $70 \mathrm{ml}$ of an 18 - to 24 -h-old culture. The cells were sedimented by centrifugation at $17,300 \times g$ for $15 \mathrm{~min}$ and then suspended in a volume of PBS calculated, on the basis of optical density at $420 \mathrm{~nm}\left(\mathrm{OD}_{420}\right)$, to provide a uniform cell suspension (about $1.2 \mathrm{mg}$ of 
protein per $\mathrm{ml}$ ). Each tube was inoculated with $20 \mu \mathrm{l}$ of cell suspension and incubated at $35^{\circ} \mathrm{C}$ in a rotating incubator (about 120 oscillations per min). The increases in $\mathrm{OD}_{420}$ compared with uninoculated cultures of the same composition were determined two or three times daily. The results are reported as the mean $\mathrm{OD}_{420}$ of the three cultures after subtraction of the initial $\mathrm{OD}_{420}$. Optical densities were determined with a Spectronic 20 spectrophotometer (Bausch \& Lomb, Inc., Rochester, N.Y.). Hematin was produced from hemin (recrystallized: Nutritional Biochemicals Corp., Cleveland, Ohio) as described by Myers et al. (20).

Metabolic experiments. $\left[1,4-{ }^{14} \mathrm{C}\right]$ succinic acid (specific activity, $45 \mathrm{mCi} / \mathrm{mmol}$ ), $\left[1-{ }^{14} \mathrm{C}\right]$ pyruvic acid (sodium salt; specific activity, $11.7 \mathrm{mCi} / \mathrm{mmol}$ ), L-[ $U$ ${ }^{14} \mathrm{C}$ )glutamine (specific activity, $49 \mathrm{mCi} / \mathrm{mmol}$ ), and $\mathrm{L}-$ $\left[U-{ }^{14} \mathrm{C}\right]$ glutamic acid (specific activity, $290 \mathrm{mCi} / \mathrm{mmol}$ ) were obtained from Radiochemical Centre, Amersham, England, and $\left[2,3-{ }^{14} \mathrm{C}\right]$ succinic acid (specific activity, $68 \mathrm{mCi} / \mathrm{mmol}$ ) was obtained from New England Nuclear Corp., Boston, Mass. These compounds were diluted with their unlabeled counterparts to provide $2 \mu \mathrm{mol}$ and $0.05 \mu \mathrm{Ci}$ per vessel. Formation of $\mathrm{CO}_{2}$ was determined as described previously $(42$, 43 ) but modified recently (40) in tubes ( 16 by $100 \mathrm{~mm}$ ) containing final volumes of $0.4 \mathrm{ml}$. These tubes were closed with rubber stoppers from which plastic caps containing filter paper wicks were suspended. The tubes were incubated at $35^{\circ} \mathrm{C}$ in a water bath for the times indicated below (plus a 2-min period for thermoequilibration). The reactions were stopped by injecting $0.15-\mathrm{ml}$ amounts of Hyamine hydroxide (New England Nuclear Corp.) into the caps and 0.1-ml amounts of $25 \%$ trichloroacetic acid into the reaction mixtures. After an additional 0.5 to $1.0 \mathrm{~h}$ of incubation. the caps and their wicks were transferred to vials to which $1.5 \mathrm{ml}$ of methanol and $7.5 \mathrm{ml}$ of Econofluor (New England Nuclear Corp.) were added. The carbon incorporated into macromolecules was measured by filtering the tube contents through $25-\mathrm{mm}$ membrane filters (pore size, $0.45 \mu \mathrm{m}$; Millipore Corp.. Bedford, Mass.), washing the filters twice with $5 \%$ trichloroacetic acid, and placing the filters in microvials to which $3-\mathrm{ml}$ amounts of Aquafluor 2 (New England Nuclear Corp.) were added. Radioactivity was measured with a liquid scintillation spectrometer. The amounts of $\mathrm{CO}_{2}$ and carbon incorporated were calculated from the counts per minute minus the counts per minute of control tubes without cells. the final specificity activity of the substrate, and the number of carbons labeled and were expressed as the means of triplicate specimens per milligram of protein. The variation among triplicate determinations was usually $<10 \%$.

Preparation of subcellular fractions. Well-washed cells (150 to $300 \mathrm{mg}$ of protein) were suspended in 40 $\mathrm{ml}$ of distilled water and disrupted by two passages through a French pressure cell (Aminco, Silver Spring, Md.) at $20,000 \mathrm{lb} / \mathrm{in}^{2}$. The remaining intact cells and large cell debris were removed by centrifugation at $17,000 \times g$ for $15 \mathrm{~min}$. The supernatants (designated total extracts) were reconstituted with $10 \times$ buffers. For enzyme analyses the buffer was $40 \mathrm{mM}$ (final concentration) potassium phosphate buffer ( $\mathrm{pH}$ 7.2), and for antigen analyses the buffer was $10 \mathrm{mM}$ tris(hydroxmethyl)aminomethane (Tris) hydrochloride $(\mathrm{pH}$ 7.6) containing $0.2 \%$ azide. The cell membranes of both preparations were pelleted by centrifugation at $200,000 \times g$ for $2 \mathrm{~h}$. They were removed from the enzyme extracts, but were retained from the antigen fractions after one wash and resuspension in Trisazide. The soluble enzyme extracts were stored at $-70^{\circ} \mathrm{C}$, whereas the antigen fractions were stored at $4^{\circ} \mathrm{C}$. Protein contents were determined by the method of Lowry et al. (15).

PAGE. Enzyme activity patterns were determined on $7.5 \%$ Davis disc gels and were stained for malate dehydrogenase as described previously (9) or for superoxide dismutase (SOD) as described by Beauchamp and Fridovich (3). Sodium dodecyl sulfate (SDS)-polyacrylamide slab gel electrophoresis (PAGE) of the antigen fractions was performed with $15 \%$ (wt/vol) acrylamide- $0.4 \%$ (wt/vol) bisacrylamide separating gel and $3.9 \%(\mathrm{wt} / \mathrm{vol})$ acrylamide stacking gel; both types of gels were prepared in the buffer system of Laemmli (14), except that the separating gel did not contain SDS. Protein samples were boiled for 5 min in Laemmli solubilizer and subjected to electrophoresis on a Protean Dual 16-cm slab cell (thickness, $1.5 \mathrm{~mm}$; Bio-Rad Laboratories, Richmond, Calif.) at $30 \mathrm{~mA} /$ gel. The gels were fixed in $10 \%$ trichloracetic acid for $1 \mathrm{~h}$, stained overnight with $0.2 \%$ Coomassie blue R250 in methanol-acetic acid-water (5:1:4), destained in several changes of ethanol-acetic acid-water (3:1:8), and stored in $7 \%$ acetic acid. SDS standard protein molecular weight kits were obtained from BioRad Laboratories and Bethesda Research Laboratories, Bethesda, Md.

Preparation of hyperimmune rabbit antisera. Wellwashed cells were suspended in PBS containing $0.1 \%$ formaldehyde to a concentration of approximately 1 $\mathrm{mg} / \mathrm{ml}$ and were stored in appropriate volumes at $-70^{\circ} \mathrm{C}$. Rabbits were injected subcutaneously at monthly intervals with $0.5-\mathrm{mg}$ doses mixed with equal volumes of Freund incomplete adjuvent. After four to six injections, the hyperimmune sera were collected from anesthetized rabbits by cardiac puncture.

Line-rocket immunoelectrophoresis. Lantern slides (100 by 80 by $1 \mathrm{~mm}$ ) were coated with $1 \%$ agarose (catalog no. 121852: Calbiochem, La Jolla, Calif.) in water and dried. Successive strips of $1 \%$ Litex HSA agarose (Accurate Chemical and Scientific Corp., Hicksville, N.Y.) in Tris-Tricine buffer $(0.08 \mathrm{M}$ Tris, $0.024 M$ Tricine, $0.3 \mathrm{mM}$ calcium acetate, $0.02 \%$ [wt vol] sodium azide, $\mathrm{pH} 7.6)$ were applied at $50^{\circ} \mathrm{C}$ to the plate with the aid of a heated channeled leveling plate connected to a circulating water bath, as follows: a 2 $\mathrm{ml}$ cathode agarose strip ( 80 by $15 \mathrm{~mm}$ ), a $2-\mathrm{ml}$ intermediate agarose strip ( 80 by $15 \mathrm{~mm}$ ) containing total antigen extract ( $75 \mu \mathrm{g}$ of Guadalupe strain protein or $150 \mu \mathrm{g}$ of vole agent protein), a 6-ml antibody agarose strip ( 80 by $55 \mathrm{~mm}$ ) containing $0.5 \mathrm{ml}$ of hyperimmune rabbit serum against either the Guadalupe strain or vole agent, and a $2-\mathrm{ml}$ anode agarose strip ( 80 by $15 \mathrm{~mm}$ ). Nine wells (diameter, $2.5 \mathrm{~mm}$ ) were punched in the cathode agar strip, and $1 \mu \mathrm{g}(5 \mu \mathrm{l})$ of each antigen fraction was applied, except that $2-\mu \mathrm{g}$ amounts of vole total antigen and membrane fractions were applied. Electrophoresis at $5 \mathrm{~V} / \mathrm{cm}$ was performed overnight with an LKB Multiphor apparatus equipped with a cooling plate at $4^{\circ} \mathrm{C}$ and Tris-Tricine buffer in the electrode buffer chambers. After electrophoresis, the soluble proteins were removed by pressing the slides under weight against blotting paper, 
TABLE 1. Colony isolations from strains of Rochalimaea

\begin{tabular}{|c|c|c|c|c|c|c|}
\hline \multirow{2}{*}{ Strain } & \multirow{2}{*}{$\begin{array}{l}\text { No. of days on } \\
\text { blood agar }\end{array}$} & \multicolumn{4}{|c|}{ No. of colonies with the following dilutions: ${ }^{a}$} & \multirow{2}{*}{$\begin{array}{l}\text { Recovery } \\
\text { rate }^{h}\end{array}$} \\
\hline & & $10^{-5}$ & $10^{-6}$ & $10^{-7}$ & $10^{-8}$ & \\
\hline Fuller & 11 & 13,25 & 0 & 0 & 0 & $18 / 24$ \\
\hline Guadalupe & 11 & $>100$ & 13,10 & 1,2 & 0 & $16 / 18$ \\
\hline Vole agent & 7 & $\mathrm{TMTC}^{\mathrm{c}}$ & Cont. ${ }^{d}$ & $11,12,13$ & $2,3,4$ & $16 / 18$ \\
\hline
\end{tabular}

${ }^{a}$ Initial seeds were grown in MEM medium, concentrated 5- to 10-fold by centrifugation, quickly frozen, and maintained at $-70^{\circ} \mathrm{C}$. Decimal dilutions were made in PBS, and $0.1 \mathrm{ml}$ was spread on to each blood agar plate.

${ }^{b}$ In $4 \mathrm{ml}$ of MEM medium. Growth was detected by 2 days in most cases. In some cases failure to recover colony isolates was attributable to contamination or to alkalinity due to escaping $\mathrm{CO}_{2}$. Twelve isolates of each strain were retained for further study, but one Guadalupe isolate was later discarded. The other tubes were discarded by 6 days.

c TMTC, Too many to count.

${ }^{d}$ Cont., Contaminated.

washing the slides with saline twice, repeating the pressing procedure, and drying in air. The slides were stained with Coomassie blue as described above for SDS-PAGE.

\section{RESULTS}

Clone isolations. The experiment leading to clone isolations is portrayed in Table 1 . The vole agent appeared to grow more rapidly on blood agar and to have a higher titer than the other two strains. A total of 12 isolates of each strain (11 in the case of the Guadalupe strain) appeared to be identical in fluorescent antibody reactions with rabbit antisera elicited by the three strains and in the migration patterns of their solubilized proteins in polyacrylamide gels. The differences among the three strains in these reactions were the same as the differences reported previously (38). All subsequent work was done with the progeny of a single isolate in each case (from the $10^{-5}$ dilution of the Fuller strain, the $10^{-7}$ dilution of the Guadalupe strain, and the $10^{-8}$ dilution of the vole agent).

Nutritional requirements. MEM medium was used in the initial part of this work because of the excellent growth obtained with this medium on irradiated L cells $(17,39)$. With this medium, we encountered two profound differences between the Fuller and Guadalupe strains on one hand and the vole agent on the other. The former remained in suspension, whereas the vole agent settled to the bottom of the tube. The $\mathrm{OD}_{420}$ of the vole agent cultures could be determined only after vigorous blending with a Vortex mixer. The omission of sodium bicarbonate from a medium that was otherwise satisfactory had no effect on the growth of the vole agent but prevented the growth of the other two strains.

The similarity of the growth patterns of the three strains in MEM medium is shown in Fig. 1. With all three strains, little or no growth was obtained when FCS was omitted, and growth was significantly reduced in medium without YE. In other experiments (data not shown), $10 \%$
FCS and $0.1 \%$ YE were more satisfactory than lower concentrations. The omission of glutamine did not affect growth, provided that an equivalent amount of succinate $(2 \mathrm{mM})$ was present. Increasing the succinate concentration to $5 \mathrm{mM}$ did not seem to be beneficial.

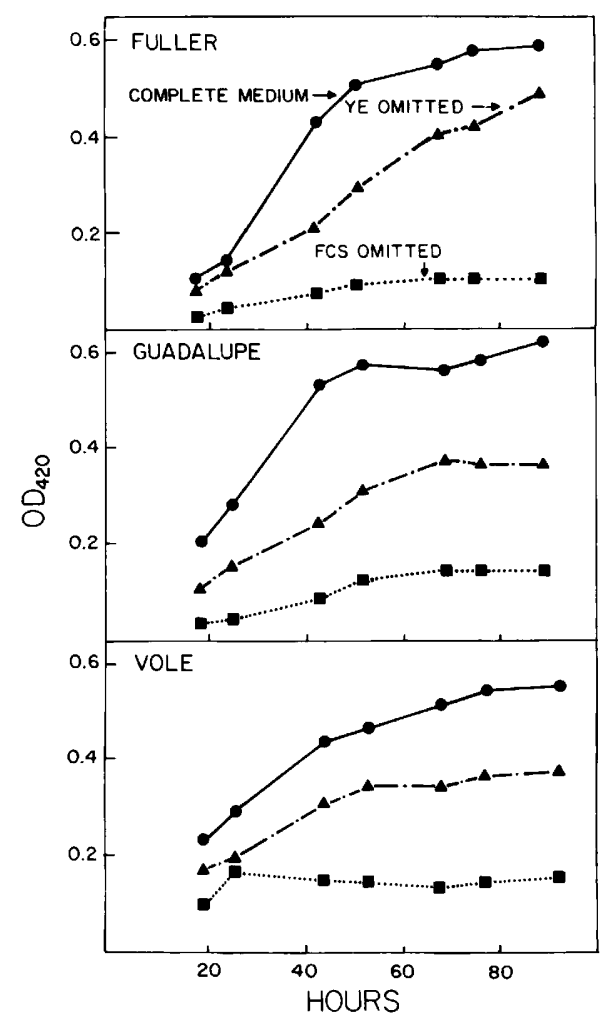

FIG. 1. Growth of three strains of Rochalimaea as measured by the increase in $\mathrm{OD}_{420}$. The complete medium consisted of Eagle minimal essential medium containing $25 \mathrm{mM}$ HEPES to which were added (final concentrations) $10 \% \mathrm{FCS}, 0.1 \% \mathrm{YE}, 2 \mathrm{mM}$ glutamine, $1 \mathrm{mM}$ succinate, and $4.5 \mathrm{mM}$ sodium bicarbonate. When a constituent was omitted, an equivalent volume of PBS was added. For other details, see text. 


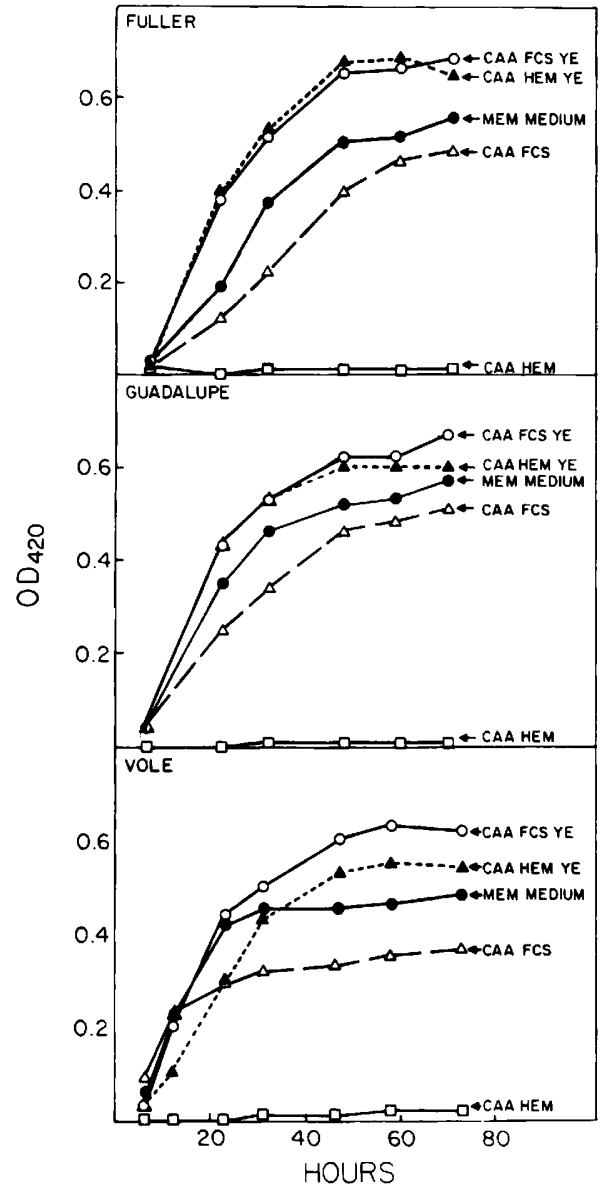

FIG. 2. Growth of three strains of Rochalimaea in complete medium (MEM medium) or media consisting of Hanks-HEPES plus (final concentrations) $2 \mathrm{mM}$ succinate, $4.5 \mathrm{mM}$ sodium bicarbonate, $0.8 \%$ CAA, and either $10 \%$ FCS or $0.02 \mathrm{mM}$ hematin (HEM) with or without $0.1 \%$ YE. For other details see the legend to Fig. 1 and the text.

An attempt to simplify the medium is shown in Fig. 2. For all three strains, Eagle minimal essential medium could be replaced by $0.8 \%$ Casamino Acids (CAA) (Difco). CAA appeared to be somewhat more satisfactory than other products of a similar nature, including CAA for vitamin assays, and was autoclavable. FCS could be replaced by hematin. The concentration used $(0.02 \mathrm{mM}$, or approximately $12.7 \mu \mathrm{g} /$ $\mathrm{ml})$ was about the same as the concentration shown to be approximately optimal for the Fuller strain by Myers et al. (20). However, with hematin YE proved to be essential rather than stimulatory. The CAA medium appeared to be equally satisfactory with FCS or hematin in the case of the Fuller and Guadalupe strains, but not quite as satisfactory with hematin in the case of the vole agent. The CAA medium appeared to stimulate the growth of all three strains as well or better than the MEM medium.

Hematin had the disadvantage that it tended to produce a black precipitate, presumably heme, that adhered tenaciously to the cells. This was particularly true of the vole agent, which readily sedimented, and was possibly the reason why growth with hematin was not as satisfactory with this agent as with the other strains. Thus, all subsequent experiments were done with Hanks-HEPES buffer (lacking glucose and $\mathrm{CaCl}_{2}$, the absence of which did not appear to affect growth) containing $10 \% \mathrm{FCS}, 0.1 \% \mathrm{YE}, 2$ $\mathrm{mM}$ succinate, and $4.5 \mathrm{mM}$ sodium bicarbonate. The minimal inoculum required for growth in this medium was not determined, but good growth was obtained with inocula diluted $1: 10$ or 1:100. Generation times, which were calculated from delays by cultures to achieve an $\mathrm{OD}_{420}$ of 0.3 with dilute inocula, were approximately (means of two experiments) $5.8 \mathrm{~h}$ for the Fuller strain, $6.7 \mathrm{~h}$ for the Guadalupe strain, and $4.7 \mathrm{~h}$ for the vole agent.

Metabolism. It was shown previously $(10,39)$ and we confirmed that the three strains did not catabolize glucose or glucose 6-phosphate. Other substrates were catabolized to variable degrees. However, consistent results were obtained when the cells were harvested while they were still multiplying and were well washed. The retention of even small amounts of medium altered the results. Succinate as the sole substrate (with only Hanks-HEPES) was rapidly catabolized. Pyruvate and glutamine were also utilized quite well, with due consideration that the study of pyruvate catabolism was limited to carbon 1. A major difference was encountered in the catabolism of glutamate. Compared with succinate, this compound was utilized at least 10 times more rapidly by the vole agent than by the other two strains. These results (Table 2) confirmed the results obtained previously in experiments with single strains $(10,39)$.

Most surprising were the results obtained with suspending fluid containing 25\% medium (Table 2 ). The catabolism of glutamate was increased about 40 -fold with the Fuller strain and 17 -fold with the Guadalupe strain, whereas it was reduced somewhat with the vole agent. These results suggest that an independent source of energy was required for the transport of glutamate in the first two strains. This hypothesis was confirmed in an experiment with the Fuller strain (Table 3). The addition of succinate, pyruvate, and particularly glutamine greatly enhanced the metabolism of glutamate. On the other hand, added glucose or adenosine triphosphate did not influence the metabolism of this compound. Although not as effective as individ- 
TABLE 2. $\mathrm{CO}_{2}$ formation from various substrates by three strains of Rochalimaea

\begin{tabular}{|c|c|c|c|c|c|c|c|c|}
\hline \multirow{3}{*}{ Suspension fluid } & \multirow{3}{*}{$\begin{array}{l}\text { Labeled } \\
\text { substrate } \\
(5 \mathrm{mM})\end{array}$} & \multirow{3}{*}{$\begin{array}{c}\text { C position } \\
\text { of label }\end{array}$} & \multicolumn{6}{|c|}{ Relative $\mathrm{CO}_{2}$ formation from $\mathrm{C}$ in labeled positions (\%) } \\
\hline & & & \multicolumn{2}{|c|}{ Fuller strain } & \multicolumn{2}{|c|}{$\begin{array}{l}\text { Guadalupe } \\
\text { strain }\end{array}$} & \multicolumn{2}{|c|}{ Vole agent } \\
\hline & & & $1 \mathrm{~h}$ & $2 \mathrm{~h}$ & $1 \mathrm{~h}$ & $2 \mathrm{~h}$ & $1 \mathrm{~h}$ & $2 \mathrm{~h}$ \\
\hline \multirow[t]{4}{*}{ Hanks-HEPES } & Succinate & $1-4^{\prime \prime}$ & $100^{h}$ & 100 & 100 & 100 & 100 & 100 \\
\hline & Pyruvate & 1 & 22 & 19 & 18 & 16 & 60 & 52 \\
\hline & Glutamine & $1-5$ & 61 & 62 & 67 & 66 & 90 & 91 \\
\hline & Glutamate & $1-5$ & 6 & 5 & 6 & 5 & 79 & 76 \\
\hline $25 \%$ Medium in & Succinate & $1-4$ & 114 & 128 & 59 & 58 & 85 & 87 \\
\hline \multirow{3}{*}{ Hanks-HEPES } & Pyruvate & 1 & 79 & 71 & 46 & 41 & 55 & 58 \\
\hline & Glutamine & $1-5$ & 33 & 51 & 17 & 22 & 44 & 53 \\
\hline & Glutamate & $1-5$ & 199 & 232 & 89 & 94 & 57 & 34 \\
\hline
\end{tabular}

"Sum of results obtained with $\left[1,4-{ }^{14} \mathrm{C}\right]$ succinate and $\left[2,3-{ }^{14} \mathrm{C}\right]$ succinate.

${ }^{b}$ The $100 \%$ values after 1 and $2 \mathrm{~h}$ were as follows: 1.93 and $3.20 \mu \mathrm{mol}$ of $\mathrm{CO}_{2}$ per mg of protein, respectively, for the Fuller strain; 1.69 and $3.05 \mu \mathrm{mol}$ of $\mathrm{CO}_{2}$ per $\mathrm{mg}$ of protein, respectively, for the Guadalupe strain; 1.63 and $2.43 \mu \mathrm{mol}$ of $\mathrm{CO}_{2}$ per $\mathrm{mg}$ of protein, respectively, for the vole agent. Each vessel contained 0.32 to $0.35 \mathrm{mg}$ of protein.

' Final concentrations of medium constituents (exclusive of added substrate): FCS, 2.5\%; CAA, 0.2\%; YE, $0.025 \%$; succinate, $0.5 \mathrm{mM}$; sodium bicarbonate, $1.1 \mathrm{mM}$.

ual substrates in stimulating $\mathrm{CO}_{2}$ formation from glutamate, added medium elicited increased incorporation of glutamate carbon into macromolecules. A comparable experiment was not done with the vole agent because glutamate metabolism was much more rapid and there was no indication that it was enhanced by medium.

Comparisons of proteins and antigens. The SDS-PAGE whole-cell migration patterns of the Fuller and Guadalupe strains appeared to be identical to each other and quite similar to the pattern of the vole agent (Fig. 3). Differences between the two strains of Rochalimaea quinta$n a$ and the vole agent were comparable to the differences encountered in Rickettsia prowazekii

TABLE 3. Glutamate metabolism by the Fuller strain $^{a}$

\begin{tabular}{|c|c|c|c|c|}
\hline \multirow{3}{*}{$\begin{array}{c}\text { Addition to Hanks- } \\
\text { HEPES }\end{array}$} & \multicolumn{4}{|c|}{$\%$ of activity } \\
\hline & \multicolumn{2}{|c|}{$\begin{array}{c}\mathrm{CO}_{2} \\
\text { formation }\end{array}$} & \multicolumn{2}{|c|}{$\begin{array}{c}\text { Carbon } \\
\text { incorporated }\end{array}$} \\
\hline & $1 \mathrm{~h}$ & $2 \mathrm{~h}$ & $1 \mathrm{~h}$ & $2 \mathrm{~h}$ \\
\hline None & 2 & 4 & 0.0 & 0.2 \\
\hline Succinate $(5 \mathrm{mM})$ & 46 & $100^{c}$ & 2.9 & 5.2 \\
\hline Pyruvate $(5 \mathrm{mM})$ & 61 & 112 & 1.7 & 3.1 \\
\hline Glutamine $(5 \mathrm{mM})$ & 66 & 115 & 3.1 & 6.7 \\
\hline Glucose $(5 \mathrm{mM})$ & 3 & 4 & 0.1 & 0.5 \\
\hline $\operatorname{ATP}(0.5 \mathrm{mM})^{d t}$ & 3 & 5 & 0.0 & 0.1 \\
\hline $25 \%$ Medium & 40 & 74 & 5.1 & 11.7 \\
\hline
\end{tabular}

" The glutamate concentration used was $5 \mathrm{mM}$ (labeled with $\left[\mathrm{U}-{ }^{14} \mathrm{C}\right]$ glutamate).

${ }^{b}$ Medium as described in Table 2, footnote $c$.

c. The $100 \%$ value was $3.97 \mu \mathrm{mol}$ of $\mathrm{CO}_{2}$ per mg of protein. Each vessel contained $0.31 \mathrm{mg}$ of protein.

${ }^{d}$ ATP, Adenosine triphosphate. and Rickettsia typhi $(8,22,38)$. When subcellular fractions of the three strains were subjected to such comparisons, the similarity between the vole agent and the two strains of Rochalimaea quintana was even more apparent (Fig. 3). There was a remarkable parallel in the distribution of proteins along the gel, even though a number of corresponding proteins did not migrate identically. The more obvious differences involved some of the minor components of the supernatant fractions and a few of the large protein components of the membrane fractions. The membrane washes contained one major protein component which reacted identically in serological tests (data not shown). As with the whole-cell patterns, reproducible differences between the Fuller and Guadalupe strains were not encountered.

Direct evidence that some of the proteins are homologous was provided by line-rocket immunoelectrophoresis (Fig. 4). When this technique was used, immunological identity was indicated by the complete continuity of the rocket immunoprecipitates with the line antigen immunoprecipitates, a continuity which resulted in a deflected line-rocket pattern (1). By this criterion, the vole agent contained at least three soluble antigens that were also present in the Rochalimaea quintana strains, but membrane and soluble antigens specific to the vole agent and to Rochalimaea quintana were also detected. In this comparison also, the Fuller and Guadalupe strains appeared to be identical qualitatively and quantitatively, as judged by rocket peak height (Fig. 4). Line-rocket immunoelectrophoresis results with antiserum against the Fuller strain (data not shown) were similar to those obtained 


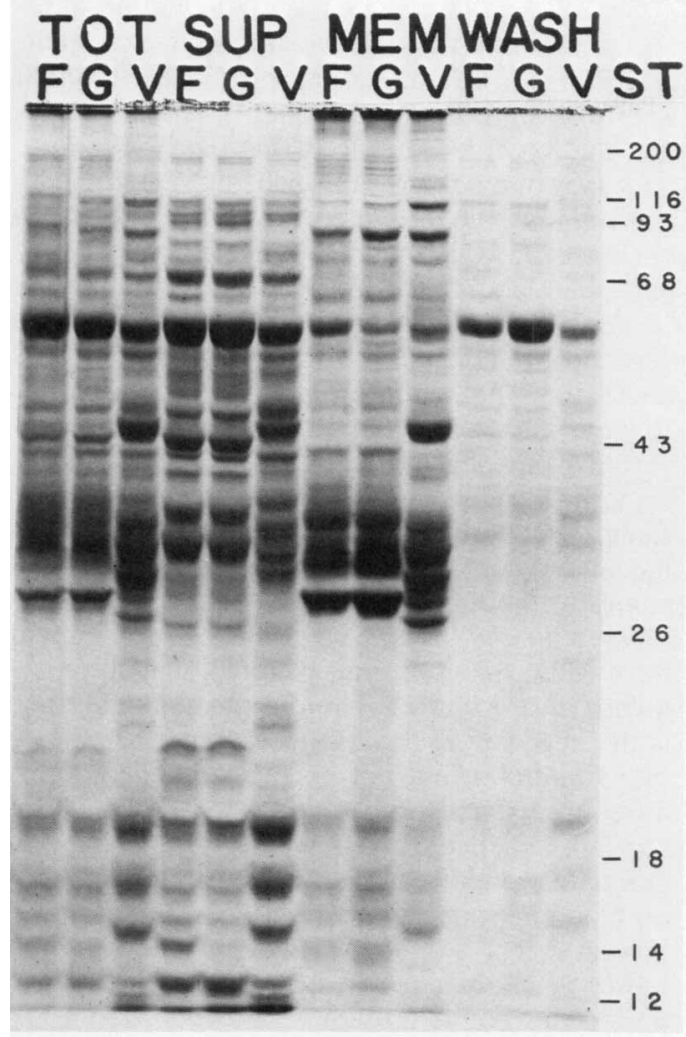

FIG. 3. SDS-PAGE analysis of cell fractions of the following three strains of Rochalimaea: Fuller (F), Guadalupe (G), and vole agent (V). Samples $(50 \mu \mathrm{g})$ of total extract (TOT), supernatant (SUP), membrane (MEM) or membrane wash fluids (WASH) were applied to the gels as indicated. The molecular weights of standard proteins (ST) are indicated $\left(\times 10^{3}\right)$. with antiserum against the Guadalupe strain (Fig. 4), although fewer immunoprecipitates were obtained. The protein nature of these antigens was indicated by their destruction as rocket immunoprecipitates by boiling for $5 \mathrm{~min}$ (data not shown).

The same antigen preparations were also subjected to crossed immunoelectrophoresis (1). Although comparable numbers of immunoprecipitates were observed against homologous and heterologous antisera, the mobilities of the vole agent antigens in agarose and polyacrylamide gels differed significantly from the mobilities of the antigens of the two Rochalimaea quintana strains (Dasch et al., manuscript in preparation).

The electrophoretic mobilities of the enzymes present in cytoplasmic extracts were also determined on polyacrylamide gels. Although the malate dehydrogenases of all three strains migrated as single bands, the mobility of the vole agent enzyme differed markedly from the mobilities of the enzymes of the Rochalimaea quintana strains (data not shown). Multiple mobilities of the SODs of the three strains were detected, as was true of the control extract from aerobically grown Escherichia coli K-12 (Fig. 5; Fuller strain identical to Guadalupe strain [data not shown]). Although both the vole agent and $R o$ chalimaea quintana strain total SOD activities were comparable to the activity of $E$. coli, the most rapidly migrating vole agent band $\left(R_{f}, 0.69\right)$ had less activity than was present in somewhat slower major band of Rochalimaea quintana $\left(R_{f}, 0.55\right)$. Although all of the $E$. coli control SOD activity penetrated the gels as discrete bands, substantial amounts of the SOD activities of all three strains of Rochalimaea banded dif-

\section{VOLE ANTIBODY GUAD ANTIBODY}

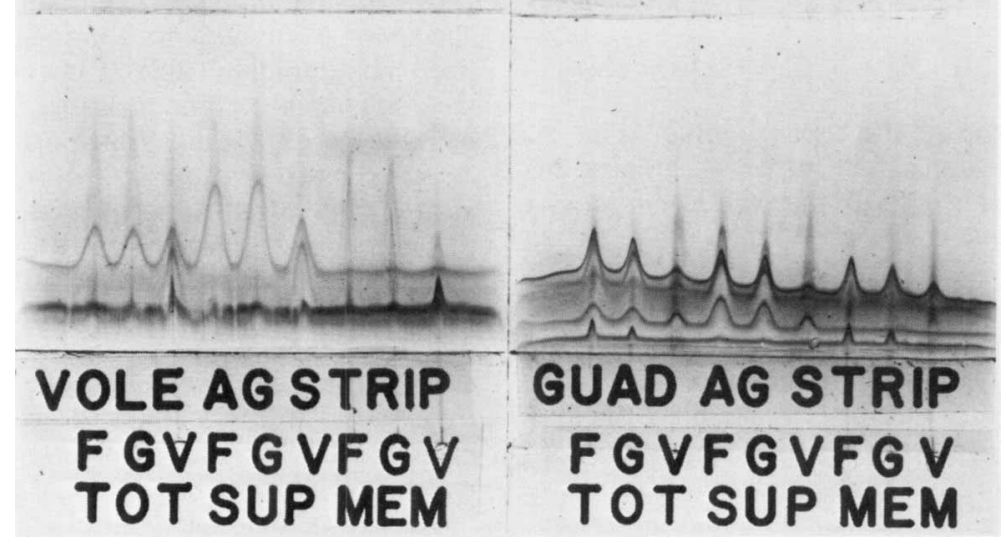

FIG. 4. Line-rocket immunoelectrophoresis of cell fractions of three Rochalimaea strains against Guadalupe strain and vole agent antisera. VOLE and V, Vole agent; GUAD and G, Guadalupe strain; F, Fuller strain; AG, antigen; TOT, total extract; SUP, supernatant; MEM, membrane fraction. For further details, see the text. 


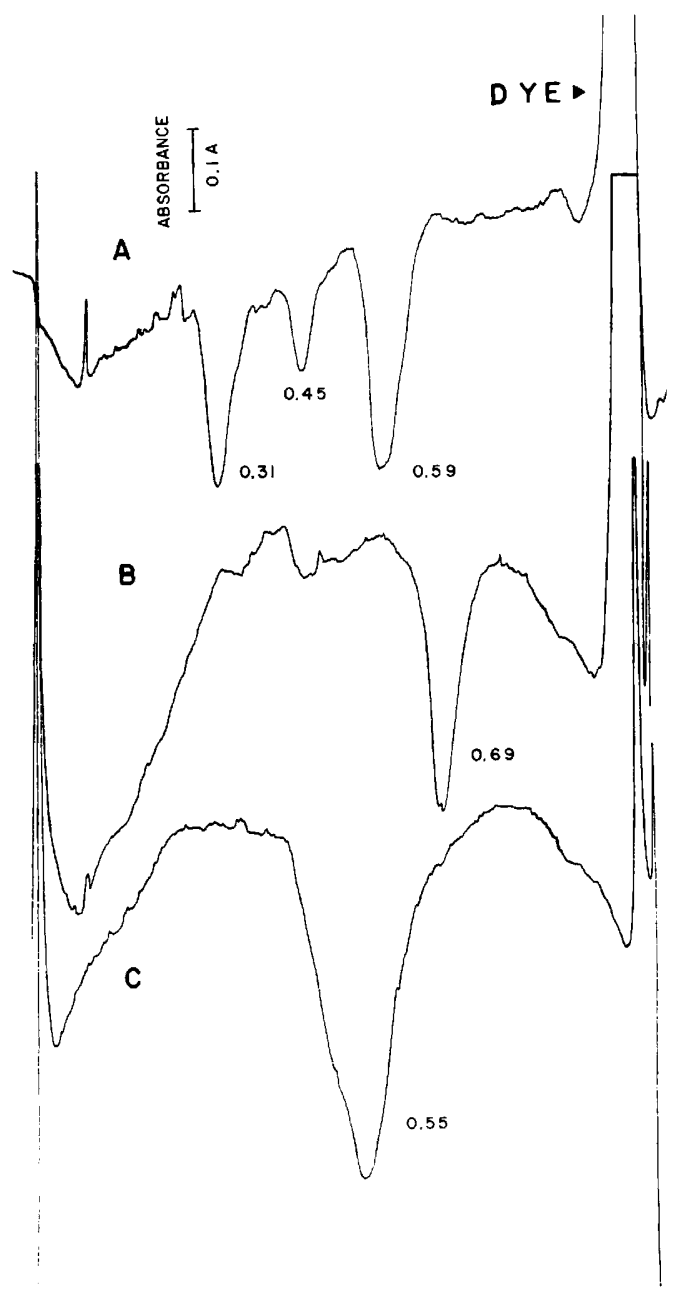

FIG. 5. Densitometric scans of polyacrylamide gels negatively stained for SOD activity. Absorbance was measured at $540 \mathrm{~nm}$. The anode was at the right (tracking dye). (A) E. coli K-12 control extract ( $250 \mu \mathrm{g}$ of protein). (B) Vole agent $(275 \mu \mathrm{g})$. (C) Guadalupe strain $(350 \mu \mathrm{g})$.

fusely at the top of the separating gel (Fig. 5). The vole agent consistently showed greater diffuse SOD staining activity than the Rochalimaea quintana strains.

\section{DISCUSSION}

Although the Fuller and Guadalupe strains were isolated from entirely different geographic locations, none of the tests conducted thus far has identified differences that can be demonstrated consistently. Thus, these two strains are considered members of Rochalimaea quintana. On the other hand, in addition to obvious similarities to Rochalimaea quintana, the vole agent displays important differences.
One distinguishing characteristic is the autoagglutination of the vole agent in buffer or medium. Whether this was a property of the original isolate or represents a "smooth-to-rough" variation that emerged during the 44 passages in the yolk sacs of chicken embryos is not known. The Rochalimaea quintana strains have not been passaged in yolk sacs. J. William Vinson (unpublished data) mentioned smooth and rough variants of the vole agent, but his description was too brief to allow proper evaluation. It is interesting that another member of the order Rickettsiales, Coxiella burnetii, is regularly converted from phase I to phase II (analogous to smooth-to-rough variation) upon repeated yolk sac passage (5). Therefore, it is conceivable that the auto-agglutinability of the vole agent is a laboratory-induced change.

Rochalimaea quintana and the vole agent have remarkably similar nutritional requirements (Fig. 1 and 2). The only major difference is the need for added $\mathrm{CO}_{2}$ pressure by Rochalimaea quintana but not by the vole agent. This difference was also observed by J. William Vinson (unpublished data), who also stated that two graduate students had cultivated the vole agent on blood agar at Harvard University and in the laboratory of James A. Baker. We were not aware of these unpublished data when we reported the axenic growth of the vole agent (39). A difference in $\mathrm{CO}_{2}$ requirement is often encountered among related microorganisms and has been described recently for Rickettsia (13). Typhus and Rocky Mountain spotted fever rickettsiae, but not Rickettsia tsutsugamushi, require $\mathrm{CO}_{2}$ enrichment when they are cultivated in chicken embryo cell cultures.

Rochalimaea quintana and the vole agent also resemble each other in their metabolism of exogenous substrates. Lack of glycolytic activity is a property that these organisms share with the genus Rickettsia (37). Of the substrates tested, succinate, pyruvate, and glutamine were catabolized most rapidly (Table 2). Although succinate metabolism is common among bacteria, some bacteria do not readily transport this substrate, as is the case in Rickettsia (44). Neisseria meningitidis catabolizes added succinate only when this compound is provided with another source of energy, such as glutamate (36). The situation is reversed in Rochalimaea quintana, which utilizes glutamate only in the presence of another substrate, such as glutamine, succinate, or pyruvate (Table 3 ). Thus, the major difference encountered between Rochalimaea quintana and the vole agent lies in the transport but not necessarily the metabolism of glutamate. Differences in ornithine metabolism (40) are somewhat more complex, involving the requirement of energy for transport by Rochalimaea quintana 
and induction of decarboxylase activity by the vole agent. Both microorganisms produce SOD (Fig. 5), a property which they share with Rickettsia (Dasch et al., manuscript in preparation). Manometric tests of catalase activity have been negative in both Rochalimaea quintana (20) and Rickettsia prowazekii (21), but the vole agent has not been tested by comparable techniques.

Although many of the metabolic functions of Rochalimaea quintana and the vole agent are entirely comparable, the enzymes involved are not necessarily identical proteins, as indicated by differences in the migration patterns of malate dehydrogenase and SOD. Similarly, although SDS-PAGE analyses of the proteins in the various subcellular fractions do not permit precise comparisons of the molecular weights of the homologous proteins (Fig. 3), the broad similarities of these patterns, coupled with the multiple immunological cross-reactivities of proteins in these fractions (Fig. 4), are compatible with the view that many of the mutations reflected in differences in migration patterns did not result in significant changes in protein function. Thus, the results obtained in this study confirm that Rochalimaea quintana and the vole agent are evolutionarily closely related and agree with the evidence (22) that at least one-third of their genomes is capable of DNA-DNA hybridization.

If these two microorganisms do indeed have a common ancestor, their entirely different ecologies have to be explained. Two hypotheses can be offered. (i) Baker (2) was essentially correct in assuming that on Grosse Isle he would find a vestige of the 19th century epidemic. He did not recover the typhus rickettsia, but recovered an agent of identical human ecology. Differences between Rochalimaea quintana and the vole agent can be attributed to their residence for a period of 100 years in two different hosts, humans and voles. This hypothesis is supported by the failure to find the vole agent in other surveys of vole populations. Such surveys $(4,12)$ were directed toward the detection of the spotted fever group of rickettsiae but would have led to the isolation of the vole agent, if it had been present. (ii) Both agents have a vole origin. At the outbreak of trench fever during World War I, the disease was attributed to the enormous infestation of the trenches with voles (25). The rodent involved was probably Arvicola terrestris, which is closely related to Microtus (William L. Jellison, personal communication). This theory was rejected when the cycle of trench fever in humans and lice was elucidated (28). However, it is possible that before its establishment in humans, the ancestor of the agent of trench fever was a rodent parasite.

We propose the name Rochalimaea vinsonii sp. nov. for the Canadian vole agent described by Baker in 1946 (2). The name is in honor of $\mathrm{J}$. William Vinson, who, in collaboration with Henry S. Fuller, first established that the genus Rochalimaea can be cultivated axenically and initiated the investigation of this genus by conventional microbiological methods. The phenotypic characteristics of this organism are as follows: Rochalimaea vinsonii is a small, gramnegative, nonflagellated, nonmotile bacterium that can be grown on blood agar or in a liquid medium containing amino acids, YE, and hematin or FCS. Succinate, pyruvate, glutamine, and glutamate can serve as sole sources of energy, but glucose is not metabolized. When grown in fibroblast cell cultures, the organism adheres to the surfaces of the cells but does not grow intracellularly. Its ecology is largely unknown, since it has been isolated only from voles on a small Canadian island. It closely resembles $R o-$ chalimaea quintana with the following exceptions: added $\mathrm{CO}_{2}$ is not required for growth; glutamate is catabolized as the sole substrate about as well as glutamine, succinate, and pyruvate, whereas Rochalimaea quintana requires another substrate for significant glutamate utilization; and ornithine decarboxylase activity is inducible, whereas it is constitutive in Rochalimaea quintana. Rochalimaea vinsonii also tends to autoagglutinate and settle to the bottom in liquid media, but this may be a strain characteristic rather than a species characteristic. Final identification of an isolate as Rochalimaea vinsonii requires appropriate serological methods and is aided by comparative studies of protein migration patterns and DNA polynucleotide base sequences. The type and only presently available strain was isolated by Baker in 1943 and is maintained as the 45 th yolk sac passage by the American Type Culture Collection (ATCC VR-152).

\section{ACKNOWLEDGMENTS}

We thank Susumu Ito of Harvard University for bringing to our attention the unpublished reports of the late J. William Vinson and for giving us permission to mention them. We also thank B. L. Ward and H. K. Mamay for participation in some of the experiments, Jerry G. Croley and Elinor A. Mody for technical assistance, and Donna M. Boyle for the preparation of the manuscript.

This work was supported by the Naval Medical Research and Development Command (Research Work Unit no. MR00001.001.1271).

\section{REPRINT REQUESTS}

Address reprint requests to: Dr. Emilio Weiss, Naval Medical Research Institute, Bethesda, MD 20814.

\section{LITERATURE CITED}

1. Axelsen, N. H., J. Krøll, and B. Weeke (ed.). 1973. A manual of quantitative immunoelectrophoresis: methods and applications. Scand. J. Immunol. 2(Suppl. 1):1-169.

2. Baker, J. A. 1946. A rickettsial infection in Canadian voles. J. Exp. Med. 84:37-51. 
3. Beauchamp, C. O., and I. Fridovich. 1971. Superoxide dismutase: improved assays and an assay applicable to acrylamide gels. Anal. Biochem. 44:276-287.

4. Bozeman, F. M., A. Shirai, J. W. Humphries, and H. S. Fuller. 1967. Ecology of Rocky Mountain spotted fever. II. Natural infection of wild mammals and birds in Virginia and Maryland. Am. J. Trop. Med. Hyg. 16:48-59.

5. Brezina, R. 1978. Phase variation phenomenon in Coxiella burnetii, p. 221-235. In J. Kazár, R. A. Ormsbee, and I. N. Tarasevich (ed.), Rickettsiae and rickettsial diseases. VEDA, Bratislava, Czechoslovakia.

6. Codeleoncini, E. 1946. Sulla presenza in Etiopia della Rickettsia weigli. Boll. Soc. Ital. Med. Igiene Trop. Sezione Eritrea 6:129-151.

7. Coolbaugh, J. C., J. J. Progar, and E. Weiss. 1976. Enzymatic activities of cell-free extracts of Rickettsia typhi. Infect. Immun. 14:298-305.

8. Dasch, G. A., J. R. Samms, and E. Weiss. 1978. Biochemical characteristics of typhus group rickettsiae with special attention to the Rickettsia prowazekii strains isolated from flying squirrels. Infect. Immun. 19:676-685.

9. Dasch, G. A., and E. Weiss. 1977. Characterization of the Madrid E strain of Rickettsia prowazekii purified by Renografin density gradient centrifugation. Infect. Immun. 15:280-286.

10. Huang, K.-Y. 1967. Metabolic activity of the trench fever rickettsia, Rickettsia quintana. J. Bacteriol. 93:853-859.

11. Ito, S., and J. W. Vinson. 1965. Fine structure of Rickettsia quintana cultivated in vitro and in the louse. J. Bacteriol. 80:481-495.

12. Jackson, E. B., J. X. Danauskas, M. C. Coale, and J. E. Smadel. 1957. Recovery of Rickettsia akari from the Korean vole, Microtus fortis pelliceus. Am. J. Hyg. 66:301-308.

13. Kopmans-Gargantiel, A. I., and C. L. Wisseman, Jr. 1981. Differential requirements for enriched atmospheric carbon dioxide content for intracellular growth in cell culture among selected members of the genus Rickettsia. Infect. Immun. 31:1277-1280.

14. Laemmli, U. K. 1970. Cleavage of structural proteins during the assembly of the head of bacteriophage T4. Nature (London) 227:680-685.

15. Lowry, O. H., N. J. Rosebrough, A. L. Farr, and R. J. Randall. 1951. Protein measurement with the Folin phenol reagent. J. Biol. Chem. 193:265-275.

16. Mason, R. A. 1970 . Propagation and growth of Rickettsia quintana in a new liquid medium. J. Bacteriol. 103:184190 .

17. Merrell, B. R., E. Weiss, and G. A. Dasch. 1978. Morphological and cell association characteristics of Rochalimaea quintana: comparison of the vole and Fuller strains. J. Bacteriol. 135:633-640.

18. Mooser, H., A. Leemann, S. H. Chao, and H. U. Gubler. 1948. Beobachtungen an Fünftagefieber. Schweiz. Z. Allg. Pathol., Bakteriol. 11:513-522.

19. Myers, W. F., L. D. Cutler, and C. L. Wisseman, Jr. 1969. Role of erythrocytes and serum in the nutrition of Rickettsia quintana. J. Bacteriol. 97:663-666.

20. Myers, W. F., J. V. Osterman, and C. L. Wisseman, Jr. 1972. Nutritional studies of Rickettsia quintana: nature of the hematin requirement, J. Bacteriol. 109:89-95.

21. Myers, W. F., L. E. Warfel, and C. L. Wisseman, Jr. 1978. Absence of hydrogen peroxide production by or catalase action in Rickettsia prowazeki. J. Bacteriol. 136:452-454

22. Myers, W. F., C. L. Wisseman, Jr., P. Fiset, E. V. Oaks, and J. F. Smith. 1979. Taxonomic relationship of vole agent to Rochalimaea quintana. Infect. Immun. 26:976983.

23. Pshenichnov, A. V. 1959. Results of many years' com- bined study of trench fever. J. Microbiol. Epidemiol. Immunobiol. (USSR) 28:1392-1397.

24. Pshenichnov, A. V., R. A. Pshenichnov, A. A. Pecherkina, and A. N. Plaksina. 1965. Cultivation of pathogenic rickettsiae in cell-free semisynthetic nutrient medium. Fed. Proc. Transl. Suppl. 24:T31-T33.

25. Rutherford, W. J. 1916. Trench fever: the field vole a possible origin. Br. Med. J. 2:386-387.

26. Sikora, H. 1921. Uber die Züchtung der Rickettsia pediculi. Arch. Schiffs Trop. Hyg. 25:123-124.

27. Sparrow, H. 1961. Sur une souche de Rickettsia quintana isolée en Tunisie. Pathol. Microbiol. 24(Suppl):140-148.

28. Strong, R. P. (ed.) 1918. Trench fever. Report of Commission, Medical Research Committee, American Red Cross. Oxford University Press, Oxford.

29. Tyeryar, F. J., Jr., E. Weiss, D. B. Millar, F. M. Bozeman, and R. A. Ormsbee. 1973. DNA base composition of rickettsiae. Science 180:415-417.

30. Varela, G., R. Fournier, and H. Mooser. 1954. Presencia de Rickettsia quintana en piojos Pediculas humanus de la Ciudad de Mexico. Inoculation experimental. Rev. Inst. Salubr. Enferm. Trop. Mexico City 14:39-42.

31. Varela, G., J. W. Vinson, and C. Molina-Pasquel. 1969. Trench fever. II. Propagation of Rickettsia quintana on cell-free medium from the blood of two patients. Am. J. Trop. Med. Hyg. 18:708-712.

32. Vinson, J. W. 1964 . Etiology of trench fever in Mexico. Ind. Trop. Health 5:109-114.

33. Vinson, J. W. 1966. In vitro cultivation of the rickettsial agent of trench fever. Bull. W.H.O. 35:155-164.

34. Vinson, J. W., and H. S. Fuller. 1961. Studies on trench fever. I. Propagation of rickettsia-like microorganisms from a patient's blood. Pathol. Microbiol. 24(Suppl.):152166 .

35. Vinson, J. W., G. Varela, and C. Molina-Pasquel. 1969. Trench fever. III. Induction of clinical disease in volunteers inoculated with $R$. quintana propagated on blood agar. Am. J. Trop. Med. Hyg. 18:713-722.

36. Weiss, E. 1970. Catabolic activities of Neisseria meningitidis: utilization of succinate. J. Bacteriol. 101:133-137.

37. Weiss, E. 1973. Growth and physiology of rickettsiae. Bacteriol. Rev. 27:259-283.

38. Weiss, E. 1981. Biochemistry and metabolism of rickettsiae: current trends, p. 387-400. In W. Burgdorfer and R. L. Anacker (ed.), Rickettsiae and rickettsial diseases. Academic Press, Inc., New York.

39. Weiss, E., G. A. Dasch, D. R. Woodman, and J. C. Williams. 1978. Vole agent identified as a strain of the trench fever rickettsia, Rochalimaea quintana. Infect. Immun. 19:1013-1020.

40. Weiss, E., H. K. Mamay, and G. A. Dasch. 1982. Ornithine metabolism in the genus Rochalimaea. J. Bacteriol. 150:245-250.

41. Weiss, E., and J. W. Moulder. 1974. Genus II. Rochalimaea (Macchiavello) Krieg 1961, 162, p. 890-891. In R. E. Buchanan and N. E. Gibbons (ed.), Bergey's manual of determinative bacteriology, 8 th ed. The Williams \& Wilkins Co., Baltimore.

42. Weiss, E., M. G. Peacock, and J. C. Williams. 1980. Glucose and glutamate metabolism of Legionella pneumo phila. Curr. Microbiol. 4:1-6.

43. Weiss, E., Rees, H. B., Jr., and J. R. Hayes. 1967. Metabolic activity of purified suspensions of Rickettsia rickettsi. Nature (London) 213:1020-1022.

44. Wisseman, C. L., Jr., F. E. Hahn, E. B. Jackson, F. M. Bozeman, and J. E. Smadel. 1952. Metabolic studies of rickettsiae. II. Studies on the pathway of glutamate oxidation by purified suspensions of Rickettsia mooseri. J. Immunol. 68:251-264. 